\title{
Anaerobic Membrane Bioreactor as Highly Efficient and Reliable Technology for Wastewater Treatment-A Review
}

\author{
Meenu Jain \\ Indian Institute of Technology, Delhi, India \\ Email: meenu2015jain@gmail.com
}

How to cite this paper: Jain, M. (2018) Anaerobic Membrane Bioreactor as Highly Efficient and Reliable Technology for Wastewater Treatment-A Review. Advances in Chemical Engineering and Science, 8, 82-100.

https://doi.org/10.4236/aces.2018.82006

Received: February 25, 2018

Accepted: April 17, 2018

Published: April 20, 2018

Copyright $\odot 2018$ by author and Scientific Research Publishing Inc. This work is licensed under the Creative Commons Attribution International License (CC BY 4.0).

http://creativecommons.org/licenses/by/4.0/

\begin{abstract}
In this review paper, Anaerobic Membrane Bioreactor (AnMBR) is considering as highly efficient and reliable technology for organic material removal from wastewater with no additional energy requirement for aeration. AnMBR is a combination of conventional anaerobic technology and modern membrane system. AnMBR is cost effective alternative technology with pros of anaerobic microbial activity because Methogenic microorganism can convert organic pollutant load of wastewater into renewable energy in the form of methane rich biogas, this conversion is mainly done by transformation of organic matter into energy by high chemical oxygen demand (COD), total suspended solid (TSS) and pathogens removal. Methane rich biogas can be used as a storable source of supplemental energy for the production of heat or power thus AnMBR technology provides improved effluent quality, reliability, and efficiency over the other traditional technologies. This review paper is included the overview of AnMBR, the advantages over other wastewater treatment technology, operational constraints and the concerned factors that has affected the performances of implemented systems, applications of AnMBR for various types of wastewaters, research and development summary and future perspective for further research.
\end{abstract}

\section{Keywords}

Anaerobic Membrane Bio Reactor (AnMBR), Wastewater Treatment, Membrane Technology, Anaerobic Treatment, Fouling

\section{Introduction}

Human beings are facing environmental pollution and suitable modular treat- 
ment facilities as one of the greatest challenges in the current century. Energy crisis and environment pollution is widely increased, received much more public and professional attentions [1]. It has become enormously important to direct research efforts toward sustainable methods. Anaerobic biotechnology is a best suited term for sustainable approach, because it combines waste treatment with the recovery of useful byproducts and renewable biofuels [2].

The anaerobic membrane bioreactors (AnMBR) are being highly popular as sustainable alternative for wastewater treatment due to several advantages over other treatment technologies. In AnMBR, the sludge collected from primary treatment is treated anaerobically by mesophilic bacteria which release methane or bio gas as a byproduct, which can be combusted to generate heat or electricity required for maintaining the further processes [3]. The anaerobic membrane bioreactors (AnMBRs), is a combination of anaerobic bio reactor and Membrane unit, which provide the less energy consumption due to no additional air requirement in anaerobic bio reactor, to achieve biomass retention on membrane and to get recovery of energy in the form of Bio gas as discussed earlier. In recent years, AnMBRs have been widely reported for the treatment of textile wastewater, oil grease wastewater, and landfill leachate [4]. AnMBR was used to treat kitchen wastewater, where COD removal efficiency was over $99 \%$ after regulation of solid retention time (SRT) [1] [5].

Presently, AnMBR is considered as an established and successfully implemented technology for different industrial wastewaters treatment. The success of anaerobic wastewater treatment can be attributed to an efficient uncoupling of the solid retention time from the hydraulic retention time through biomass immobilization. This is usually accomplished through biofilm or granule formation. The separation of biomass from the effluent, using membrane technology, is another attractive method to retain the biomass within the anaerobic reactor [6]. Because of relatively high SRT in AnMBR, the longer recovery time can also be mitigated due to Interruption from shock loading, biomass washout and toxic substances. The number of peer-reviewed publications is over the past three decades. Figure 1 shows the increasing interest in AnMBR.

Apart from all advantages, Membrane fouling remains the critical obstacle limiting the more widespread application of AnMBR in wastewater treatment [7]. Accumulation of organic and inorganic fouling materials, internally in membrane pores and externally on membrane surface, reduces flux and potentially necessitates chemical cleaning or membrane replacement [8], which finally affacts the overall performance and cost of AnMBR.

This review paper is included the overview of AnMBR, the advantages over other wastewater treatment technology, factors that has affected the performances of implemented systems, existing operational difficulties, applications of AnMBR for various types of wastewaters, research and development summary and future perspective for further research. 


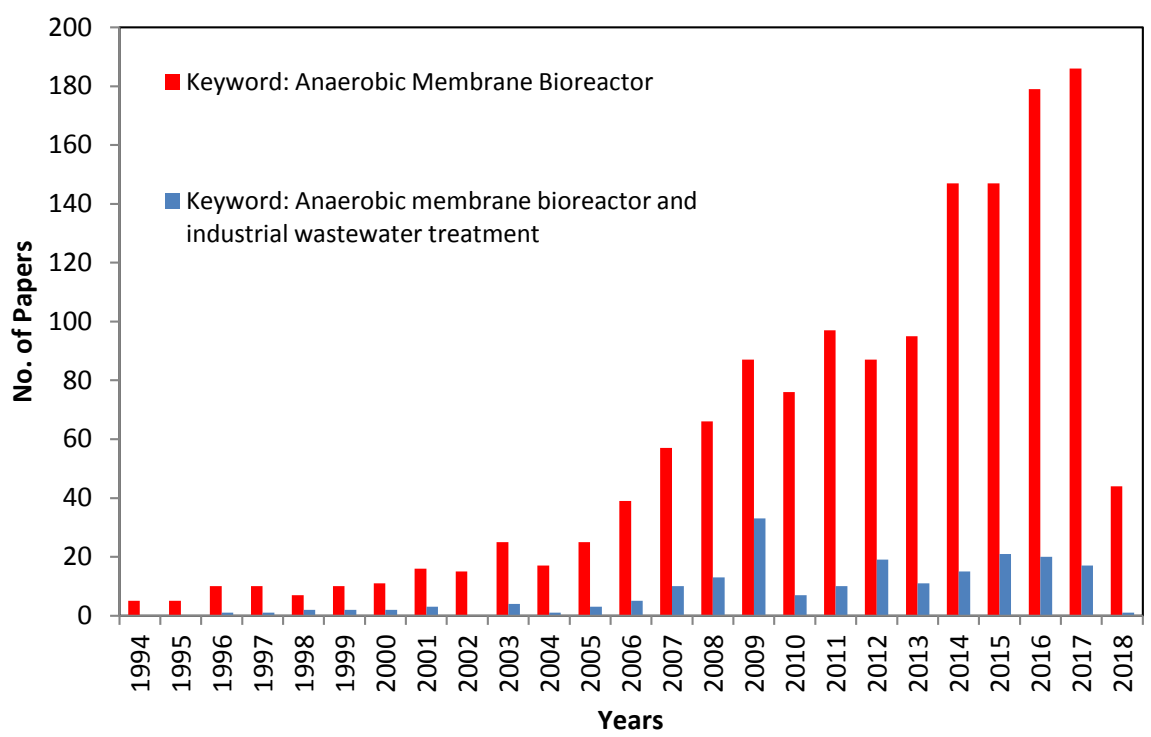

Figure 1. Number of publication over the past three decades (Scopus) using the key phrases; (a) "AnMBR" only, and (b) "AnMBR for industrial wastewater treatment". The number of publications in 2018 is shown only till February.

\section{Historic Development of Anaerobic Membrane Bio Reactor}

\subsection{Historic Development}

By the 1930s, both aerobic and anaerobic biological treatment methods had been commonly used to treat domestic and industrial wastewater [9]. During the course of these processes, organic matter, mainly in soluble form, is converted into $2 \mathrm{H}_{2} \mathrm{O}, \mathrm{CO}_{2}, \mathrm{NH}_{4}^{+}, \mathrm{CH}_{4}, \mathrm{NO}_{2}^{-}, \mathrm{NO}_{3}^{-}$and biological cells. The end products differ depending on the presence or absence of oxygen [10].

In late 1960's, the concept of an activated sludge process coupled with ultrafiltration was commercialized by Dorr-Oliver [11].

In the decade of 1970's, the quality of the final effluent from conventional biological treatment systems was highly dependent on the hydrodynamic conditions in the sedimentation tank and the settling characteristics of the sludge. Consequently, large volume sedimentation tanks was the major concerned for offering several hours of residence time required to obtain adequate solid/liquid separation [12]. The first test of the concept of using membrane filtration with anaerobic treatment of wastewater appears to have been reported [13] in 1978. The external cross-flow membrane treated septic tank effluent and resulted in an increased biomass concentration, $85 \%$ - 95\% biochemical oxygen demand (BOD) reduction, $72 \%$ nitrate removal, and $24 \%-85 \%$ orthophosphate reduction [13] [14].

In 1980, a secondary settling tank was used for the solid/liquid separation and this clarification was often the limiting factor in effluent quality [15]. The AnMBR process can be basically defined as a biological treatment process operated without oxygen and using a membrane to provide complete solid-liquid se- 
paration. AnMBRs were first introduced in the 1980s in South Africa and till it has less investigated compared to aerobic MBR [6]. The first commercially-available AnMBR was developed by Dorr-Oliver in the early 1980s for high-strength whey processing wastewater treatment and was known as the Membrane Anaerobic Reactor System (MARS) [16] [17]. The MARS process was tested at pilot scale but was not applied at full scale, possibly due to high membrane costs [18].

In the decade of 1990s, AnMBR research activity increased with investigations into different membrane materials [14] [19] [20] [21], characterization of membrane foulants [14] [22] [23] [24] and development of strategies for membrane cleaning and fouling management [14] [20] [22] [23] [25] Also, immersed membranes started implementation [14].

By the 2000s, studies on the AnMBR focused on system performance, filtration characteristics, characterization of membrane foulants, and membrane fouling control and the success of submerged aerobic MBRs in the early 2000s highly encouraged the exploration of submerged AnMBRs (SAnMBRs) for wastewater treatment [7]. In the last decade, Kubota Corporation developed a SAnMBR named "KSAMBR" process, which has been successfully applied in a number of full-scale food and beverage industries [26]. ADI Systems Inc. developed ADI-AnMBR system specific for food wastewater treatment [7]. The largest AnMBR installation up to date in the world was completed by ADI, which produced effluent free of suspended solids (SS) and with $99.4 \%$ COD removal, allowing $100,000 \mathrm{gal} / \mathrm{d}$ of wastewater to be easily discharged into the municipal system [27].

In 2009, it was indicated that AnMBR treating municipal wastewater with COD around $500 \mathrm{mg} / \mathrm{L}$ could recover methane up to $48 \%$ while the effluent COD was found bellow $40 \mathrm{mg} / \mathrm{L}$. Hence, the potentials of AnMBR applications on low strength wastewaters with the objectives of energy recovery and water reuse are valued in the future [28].

Later in 2010s, the submerged AnMBR treatment was significantly studied with attempts made to improve energy efficiency, extend the application scope and solve technical problems such as membrane fouling [7].

Since January 2018 to till date, lot of works on hydrodynamic parameter of membranes, membrane material characteristics, effect of various contaminant on performance of AnMBR, configurational development of membrane module and overall system and life cycle assessment and sustainability development work has been done on AnMBR, which opens the broad area of further research.

\subsection{Treads of Development of Biological Wastewater Treatment Technology}

Figure 2 shows the trends, from conventional wastewater treatment technology to Anaerobic Membrane Bioreactor according to microorganism suspended growth and attached growth system. Primarily treated waste water, which included screening and inorganic solid removal, used as influent for further 


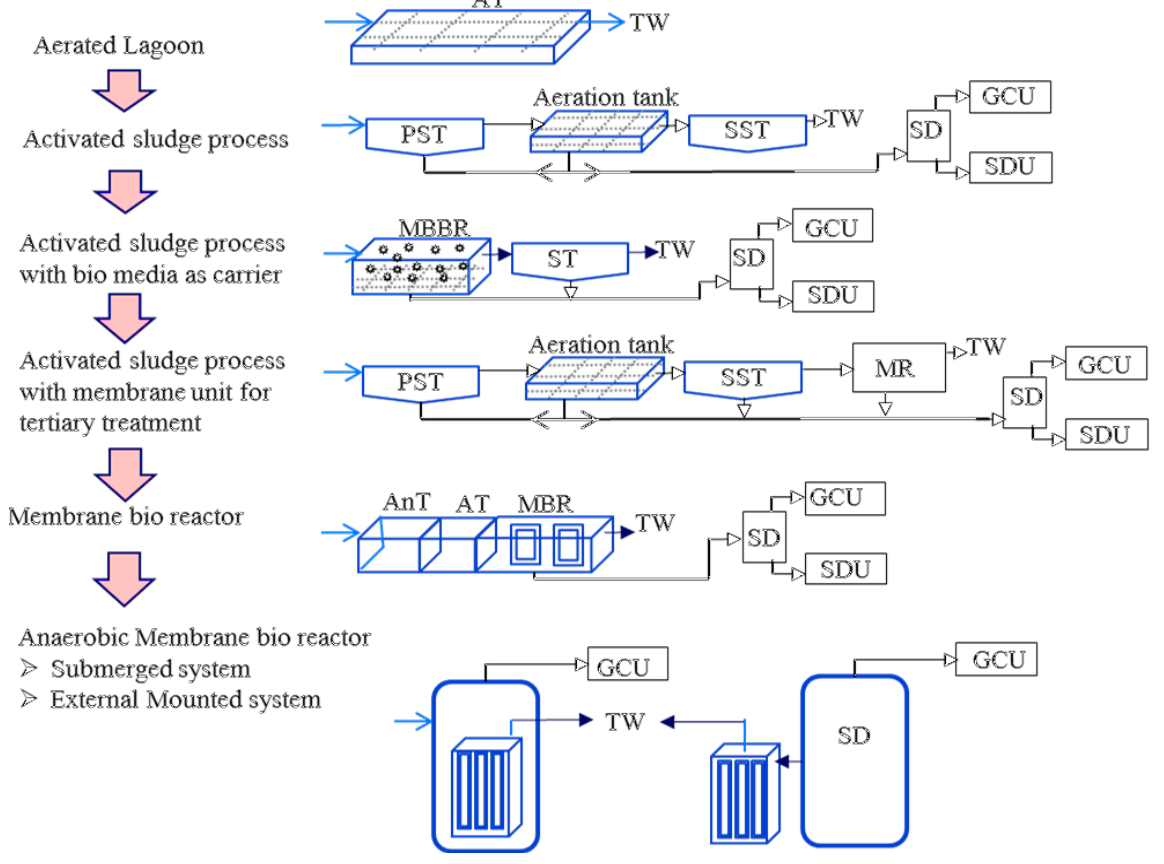

Figure 2. Treads of development of Biological wastewater treatment technology.

process treatment of figure. In starting, aerated lagoon was using for wastewater treatment where natural or artificial aeration was used for treatment process. After aerated lagoon, Activated sludge process (ASP) was introduced where primarily treated water was collected in primary settling tank (PST) for proper settling of sludge, supernatant water from PST was further treated biologically in aeration tank (AT) followed by secondary settling tank (SST) and sludge from primary and secondary treatment was collected in Sludge digester (SD), outlet gas from the top of sludge digester was collecting in Gas collecting unit (GCU) and anaerobically digested sludge from the bottom of sludge digester was collecting in sludge dewatering unit (SDU). Modification in attached growth system introduced moving bed bio reactor (MBBR) where PST and aeration unit was replaced with MBBR tank, reduced the landscape requirement. Meanwhile, for improvement in effluent quality, research was done on coupling of tertiary treatment with membrane unit which further improved and modified into membrane bioreactor (MBR), Where Anoxic tank (AnT) for denitrification followed by aerobic $\operatorname{tank}(\mathrm{AT})$ for aerobic oxidization of organic waste was also provided but energy cost was again very high for aeration requirement that influenced the anaerobically treatment coupled with membrane unit, which is AnMBR. In anaerobic membrane bioreactor (AnMBR), air requirement for aeration tank and additional sludge treatment cost was reduced due to anaerobic process, provided high quality effluent due to coupling with membrane unit.

\section{Fundamentals of Anaerobic Treatment and Membrane Technology}

Biological treatment can be of two types, 1) Aerobic and 2) anaerobic process. 
Aerobic treatment further can also be divided into two parts, 1) Suspended growth which included activated sludge process, extended aeration process and aerated lagoons, and 2) attached growth process, which includes trickling filter, moving bed bioreactor, rotating biological contractor. Anaerobic treatment includes Up-flow sludge blanket reactor and anaerobic membrane bioreactor. An AnMBR can be simply defined as a biological treatment process operated without oxygen and using a membrane to provide complete solid-liquid separation [14]. The anaerobic biological wastewater treatment process consists of two main biochemical stages such as acid formation and methane formation, The anaerobic degradation of complex organics is carried out by different groups of bacteria such as fermentative acetogens, homoacetogens, hydrogenetrophic methanogens and aceticlastic methanogens.Fermentative bacteria and acetogenesis bacteria involve in the anaerobic processes are facultative, more tolerant to environmental changes and fast growers [6]. Among those mentioned above, homoacetogens are the most concerned today [2] because of their ability to produce acetate which is the most important intermediate of methane production [2] [6] [29]. Among the anaerobes, methanogens are the most vulnerable consortia over other acedogenic or acetogenic bacteria [30] [31].

\section{AnMBR Process and Configurations}

Various membrane configurations such as flat sheet, hollow fiber, and tubular membranes are applied in AnMBRs, using different types of module configurations such as submerged/immersed and external cross-flow systems [14] [32]. AnMBR systems were essentially implemented as two configurations, based on membrane design and operation: 1) external/side-stream configuration and 2) submerged/ immersed configuration [14], where the membrane could be operated under pressure or it may be operated under vacuum. In external cross-flow membrane configuration, the membrane is separate from the bioreactor and a pump is required to push bioreactor effluent into the membrane unit and permeate through the membrane [14]. Plastic, sintered steel, and ceramic material are used for membranes. Within plastic, four types were considered: polyethersulfone (PES), polyvinylidenefluoride (PVDF), polyethylene terephthalate (PET), and polytetrafluoroethylene (PTFE). Plastic was assumed to be usable for any membrane type, but sintered steel and ceramic were limited to flat sheet and multi tubes membranes, respectively [33].

The main conclusion is the need to assess the feasibility of both side stream and submerged configurations to arrive at optimum fouling control strategies and minimize the overall energy demand [34]. Figure 3(a) and Figure 3(b) shows the schematic diagram of side-stream configuration and submerged or immersed membrane configuration with temperature (TI) and pressure indicator (PI) respectively.

\subsection{Side-Stream Configuration}

In the side-stream configuration, the recirculation pump ensures required 


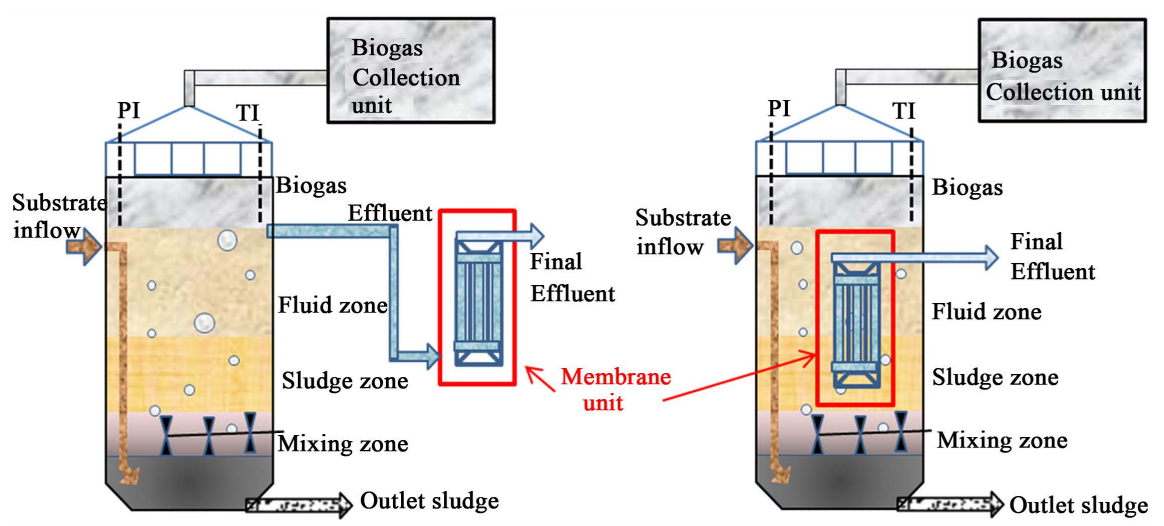

(a)

(b)

Figure 3. (a) Side-stream configuration; (b) Submerged or immersed membrane configuration.

trans-membrane pressure in the membrane chamber. As a result, cross flow velocity permanently disrupts formation of a filtration cake on the membrane's surface. While this process consumes energy, any remaining energy can be used to mix the suspension in the anaerobic reactor [14] [35]. The cross-flow velocity along the membrane's surface is typically kept within a range of $2-4 \mathrm{~m} \cdot \mathrm{s}^{-1}$, in order to achieve optimum operational efficiency as regards filtration cake removal and energy demand [36].

\subsection{Submerged Membrane}

Instead of direct pressure, the membrane is operated under a vacuum and the membrane module is directly placed into the liquid, this type of configuration is called submerged or immersed because vaccum pump or gravity is used to pull the permeate through the membrane [14]. Submerged AnMBRs can also be used in different configurations including directly immersed into the bioreactor or immersed in a separate membrane tank [14] [32]. It was found in experimental studies that compared specific energy demands for different configurations of AnMBR treating municipal wastewater was $0.3 \mathrm{~kW} \cdot \mathrm{h} / \mathrm{m}^{3}$ permeate needed for submerged configuration and $3.7 \mathrm{~kW} \cdot \mathrm{h} / \mathrm{m}^{3}$ permeate was needed for external cross-flow configurations [37]. A critical challenge for submerged systems also stems from fouling mitigation, with this analysis demonstrating the clear need to eliminate gas sparging and replace it with less energy-intensive processes [33].

\subsection{Operation and Cleaning of Membrane}

Scouring of the membrane surface is necessary to remove foulants and varies depending on the reactor configuration, influent wastewater, and operational conditions [33] [38]. Cross-flow systems utilized a high cross-flow velocity to mitigate fouling, whereas submerged AnMBRs relied on gas sparging. As an alternative to gas sparging, membrane scouring in submerged systems was also 
achieved by fluidizing a bed of GAC in direct contact with the membrane [33] [39].

\section{Energy Recovery}

AnMBRs can also play a vital role in energy recovery due to their capacity to produce $\mathrm{CH} 4$ from the utilization of a large fraction of organics in wastewaters [40]. It has great potential to achieve energy recovery and better quality effluent for reuse. Higher strength wastewaters where the higher organic exists; the energy content is much greater. Hence to recover maximum energy, anaerobic treatment must be applied to the high strength wastewater directly [6]. From the perspective of biogas production, different types of wastes, such as residues from agro-activities (manures, corn silages, etc.), bio waste from municipal solid waste, sludge from wastewater treatment plants, could be utilized [41]. AnMBRs can convert up to $98 \%$ of the influent COD into biogas and very small sludge production is normally observed due to the low growth yield of anaerobic micro-organisms, [42] [43]. Organic wastes rich in carbohydrates, such as bio waste and corn silage, can improve the biogas production and the proportion of $\mathrm{CH}_{4}$ [41]. There is a misconception that, the anaerobic bacteria or methanogens are slower than aerobic bacteria but after extensive research work it had been confirmed that anaerobic bacteria are faster and stronger than the most efficient aerobic bacteria of activated sludge process.

\section{Applications in Various Wastewater Treatments}

Membrane coupling with anaerobic process has potential of nitrogen removal by anammox process, which converts nitrite and ammonia in wastewater to nitrogen gas [44].

In an AnMBR, non-woven fabric filter and a poly-tetrafluoroethylene (PTFE) composite membranes are generally used for the treatment of low strength wastewater [29], A crossflow AnMBR to treat sewage at varying HRTs has studied, where COD loading rates of $1-2 \mathrm{~kg} C O D \mathrm{~m}^{3} \cdot \mathrm{d}^{-1}$ were applied to the AnMBR for 280 days. The effluent COD was always lower than $40 \mathrm{mg} / \mathrm{L}$, however, around $30 \%$ of the inlet COD was unable to be recovered, independent of the HRT, due to dissolved methane, sulphate reduction, and untreated COD in the permeate [28]. The amount of methane recovered from the synthetic municipal wastewater decreased from $48 \%$ to $35 \%$ when the HRT decreased from 12 to $6 \mathrm{hr}$. Therefore, operating the AnMBR at relatively long HRTs and SRTs may enhance methane recovery and reduce or eliminate sludge production [28] [29]. Figure 4 shows some general application of effluent and bio product (Energy and digested bio solid) of AnMBR.

\section{AnMBR Performance}

The AnMBR was operated at cross-flow velocities up to $1.5 \mathrm{~m} / \mathrm{s}$ and fed with a gelatin-starch-ethanol mixture [45]. A significant fraction of acidogenic biomass 


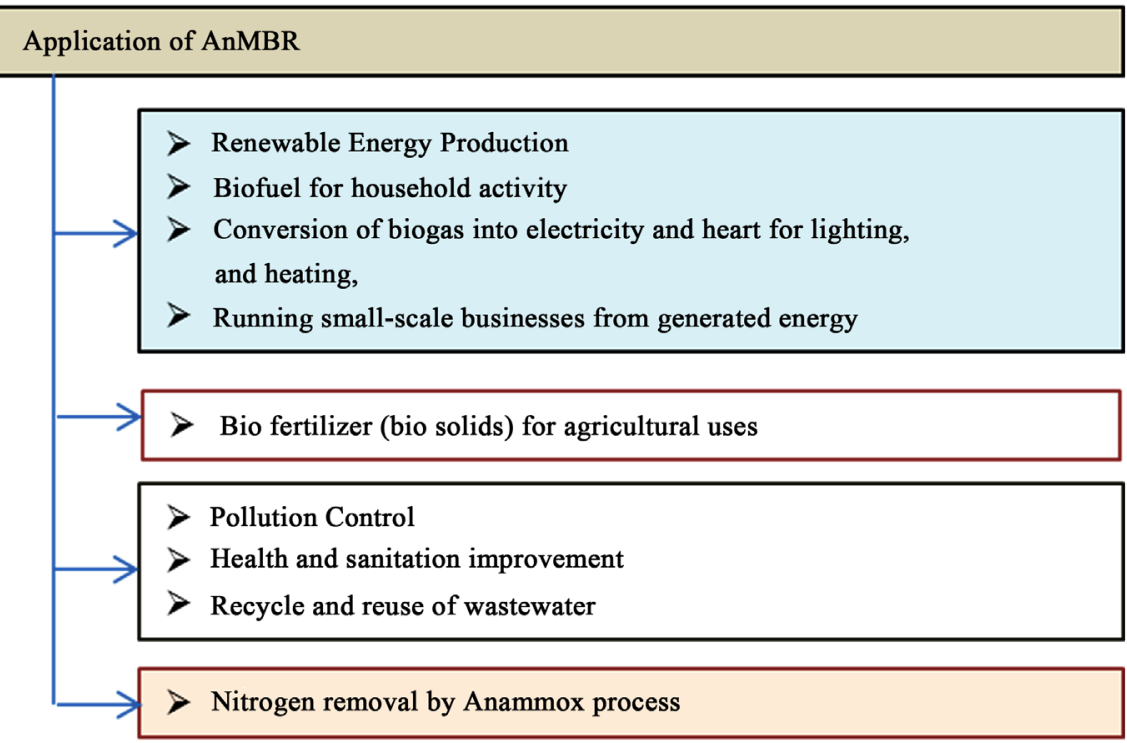

Figure 4. Applications of AnMBR.

developed during reactor operation, which fully determined the sludge rheology, and influenced the particle size distribution [45] [46]. As a result, flux levels of only $6.5 \mathrm{l} / \mathrm{m}^{2} \mathrm{~h}$ were achieved, at a liquid superficial velocity of $1.5 \mathrm{~m} / \mathrm{s}$ [45]. Continuous biogas production could be observed in AnMBR systems for various wastewaters treatment [7]. The observed methane yield ranged $0.23-0.33$ $\mathrm{LCH}_{4} / \mathrm{g}$ COD removal has been reported, which was generally lower than the theoretical yield $\left(0.382 \mathrm{LCH}_{4} / \mathrm{g} \mathrm{COD}\right.$ removal at $25^{\circ} \mathrm{C}$ [28] [47] [48] [49]. It was observed that, AnMBRs operated at $25^{\circ} \mathrm{C}$ and $15^{\circ} \mathrm{C}$ to treat synthetic municipal wastewater achieved more than $85 \%$ COD removal [50]. AnMBR is also a promising process to treat landfill leachate with high efficiency in terms of degradation yield and biogas productivity, at high organic loading rate of $6.27 \mathrm{~g}$ COD $\mathrm{l}^{-1} \cdot \mathrm{d}^{-1}$, the biogas production was more than 3 volumes of biogas per volume of the bioreactor. The treatment efficiency was high with an average COD reduction of $90 \%$ and biogas yield of 0.461 biogas per g COD removed [4]. To reduce the membrane fouling and strengthen performance of the AnMBR, adding filter was reported to be a promising option, it has been confirmed that adding granular activated carbon (GAC) to an AnMBR resulted in a reduction in the cake layer resistance by approximately 53.5\% [7] [51].

The performance of AnMBRs treating domestic wastewater (DWW) has been assessed in three recent pilot-scale studies [8] [52] [53] [54], each one of these studies indicates that treatment performance similar to that observed during bench-scale research may be obtained at a larger scale. Furthermore, it has been reported that membrane fouling may be avoided in the long-term. However, in first pilot plant study, it was highlighted that high sulfate concentrations in DWW severely reduce the potential methane generation and energy recovery of AnMBR systems [52]. Considering additional complications with sulfide corrosion and the need for biogas scrubbing, AnMBR treatment of sulfate-rich DWW 
should be avoided [8] [52].

The second pilot plant study, the pilot plant was fed with a screened raw sewage at an OLR of $0.58 \mathrm{~kg} \mathrm{COD} / \mathrm{m}^{3} /$ day, HRT of 8.5 hours and SRT of about 80 - 100 days for about 160 days. During this period the membrane was operated continuously at a flux of $17 \mathrm{LMH}$, TMP of less than $5 \mathrm{kPa}$ and no membrane fouling was observed. The average steady state membrane tank MLSS concentration was $13.4 \mathrm{~g} / \mathrm{L}$ and critical flux was found in the range of $26 \mathrm{LMH}$. The BOD removal rate was $85 \%$. The COD balance analysis showed that 31 percent of the incoming total COD was recovered in the form of methane; however $19 \%$ was in liquid phase and exited the system with the permeate. A significant fraction of the incoming COD was also found to be non-biodegradable and led to COD accumulation within the bioprocess tank [53].

The third pilot plant study, The Submerged AnMBR could be operated with stable filtration resistance under critical flux conditions $\left(7 \mathrm{~L} /\left(\mathrm{m}^{2} \cdot \mathrm{h}\right)\right)$ at $35^{\circ} \mathrm{C}[54]$ [55]. Nevertheless, an increase in the fouling rate probably linked to an accumulation of TSS and soluble COD in the reactor was observed at psychrophilic temperatures. Despite this accumulation, COD removal efficiencies were nearly $90 \%$ both under mesophilic and psychrophilic conditions. Effluent COD and BOD5 were lower than 80 and $25 \mathrm{mg} / \mathrm{L}$, respectively [54]. Table 1 shows the summary of all above three pilot scale plants.

\section{Factors affecting the Treatment Performance of AnMBR}

1) Low sludge yield is deemed one of the major advantages of anaerobic treatment Systems but low sludge yields require longer start-up times to attain a given biomass concentration. Start-up times can be reduced by maintaining a higher biomass inventory during the reactor start-up [2].

2) Before 1970s, the major reason of failure of many anaerobic reactors was the lack of understanding of the micronutrient requirement of methanogens. Trace amounts of iron, nickel, and cobalt are essential for optimum growth of anaerobic microorganisms (methanogens). Industrial wastewater often lacks

Table 1. Operational parameters and treatment performance results obtained in pilot-scale AnMBR studies for DWW treatment [8] [52] [53] [54] [55].

\begin{tabular}{|c|c|c|c|c|c|c|c|}
\hline $\begin{array}{c}\text { Bioreactor } \\
\text { configuration }\end{array}$ & Membrane information & $\begin{array}{c}\text { Fouling } \\
\text { control method }\end{array}$ & $\begin{array}{l}\text { Temp. } \\
\left({ }^{\circ} \mathrm{C}\right)\end{array}$ & $\begin{array}{c}\text { SRT } \\
\text { (days) }\end{array}$ & $\begin{array}{c}\text { HRT } \\
\text { (h) }\end{array}$ & $\begin{array}{l}\text { Average influent } \\
\text { strength }\end{array}$ & $\begin{array}{c}\text { Average effluent } \\
\text { (mg/L Total } \\
\text { COD } / \% \text { removal) }\end{array}$ \\
\hline $\begin{array}{l}\text { Completely mixed } \\
\text { anaerobic reactor } \\
(1 \text { st pilot-scale) }[53]\end{array}$ & $\begin{array}{l}\text { Polyvinylidene difluoride, } \\
\text { hollow-fibre ultrafiltration } \\
\text { membrane module with } \\
0.05 \mu \mathrm{m} \text { pore size }\end{array}$ & Biogas sparging & 33 & 70 & $6-21$ & $\begin{array}{l}445 \text { mg Actual } \\
\text { DWW/Ltr. Total } \\
\text { COD }\end{array}$ & $77 / 83$ \\
\hline $\begin{array}{l}\text { Completely mixed } \\
\text { anaerobic reactor } \\
\text { (2nd pilot-scale) }[54]\end{array}$ & $\begin{array}{l}\text { Polyvinylidene difluoride, } \\
\text { hollow-fibre ultrafiltration } \\
\text { membrane module }\end{array}$ & $\begin{array}{l}\text { Biogas sparging; } \\
\text { relaxation; weekly } \\
\text { chemical cleaning }\end{array}$ & 22 & $80-100$ & 8.5 & $\begin{array}{l}224 \text { mg Actual } \\
\text { DWW/Ltr. Total } \\
\text { COD }\end{array}$ & $47 / 79$ \\
\hline $\begin{array}{l}\text { Completely mixed } \\
\text { anaerobic reactor } \\
\text { (3rd pilot-scale) }[55]\end{array}$ & $\begin{array}{l}\text { flat sheet polyether sulfone } \\
\text { ultra-filtration membrane module } \\
\text { with a mean pore size of } 38 \mathrm{~nm}\end{array}$ & $\begin{array}{l}\text { Biogas sparging; } \\
\text { relaxation; } \\
\text { backflushing }\end{array}$ & 35 & 680 & 19.2 & $\begin{array}{l}630 \text { Actual DWW } \\
\text { supplemented with } \\
\text { glucose/Ltr. Total }\end{array}$ & $<80 / 90$ \\
\hline
\end{tabular}


such micronutrients and traces metals, and requires external supplementation while Municipal wastewater usually contains sufficient amounts of micronutrients and trace metals [56].

3) The Optimal parameters are mandatory for the proper growth of anaerobic microorganisms, because methanogens is highly dependent on temperature, $\mathrm{pH}$, and redox potentials.

4) In AnMBR, treatment of high-sulfate wastewater is considerably challenging, because sulfate and hydrogen sulfide reduces the methane yield and hydrogen sulfide is extremely corrosive gas and produces an objectionable odor But in last decade's experimentalist have found the solution by successful implementation of online sulfide control method [2].

5) In anaerobic treatment, Nitrogen concentrations remain unchanged, only the forms of nitrogen are changed; that is, organic nitrogen is simply transformed to inorganic ammonia or ammonium, depending on $\mathrm{pH}$ [2].

6) Salinity can be another problem for the treatment of municipal wastewater, especially for coastal residential areas with improper infrastructure which allows the infiltration of sea water into sewer systems [32].

7) During long term operation, High shear rates of membrane surface may stimulate the break-down of microbial flocs and increase the cake layer resistance due to the selective deposition of fine particles in the cake layer and membrane pores, results in the formation of a dense consolidated cake layer that is very hard to remove, Which is called as the shear rate dilemma [32] [45].

8) Temperature change plays a vital role for methanogenic activity [29] [50], it could reduce the overall performance of system. It was observed in experimental studies that methanogenic activity was suppressed at $15^{\circ} \mathrm{C}$ compared to $25^{\circ} \mathrm{C}$ [29]. Two laboratory-scale anaerobic membrane bioreactors, AnMBR 1 and AnMBR 2, were run in parallel at $25^{\circ} \mathrm{C}$ and $15^{\circ} \mathrm{C}$, respectively. Total chemical oxygen demand (COD) removal efficiency was more than $95 \%$ and $85 \%$ for AnMBR 1 and 2, respectively [50].

9) Sludge cake formation rate on membranes was found, heavily affected by biogas sparging rate and permeate flow rate, and less affected by mixed liquor suspended solid concentration under tested conditions. A higher biogas sparging rate and lower permeate rate corresponded to a lower Sludge cake formation rate on membranes [57].

10) The use of biogas sparging for membrane fouling control may also affect the metabolic behavior of anaerobic sludge. Increasing $\mathrm{CO}_{2}$ and $\mathrm{CH}_{4}$ concentrations may inhibit methanogenesis [58] [59], especially if the increased $\mathrm{CO}_{2}$ concentration leads to a decreased $\mathrm{pH}$ in the absence of $\mathrm{pH}$ control [57] [59].

Membrane types, Process Performance, Hydrodynamic conditions, process operating conditions are major factors that affect the performance of AnMBR. Membrane material characteristics may affect the degree of fouling in AnMBRs; e.g. organic and inorganic membranes may show different fouling behaviors [32]. Figure 5 shows the summary of all Factors that affects the Treatment Performance of AnMBR [60]. 


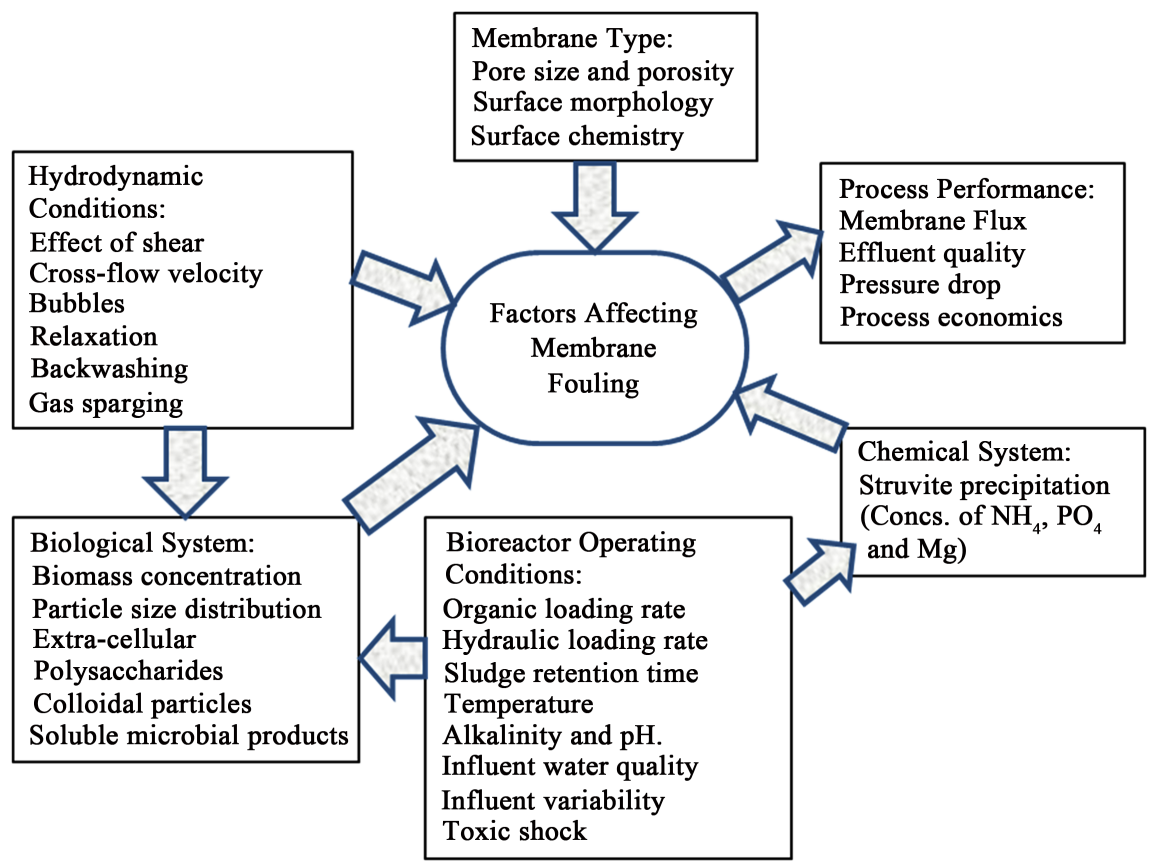

Figure 5. Parameters and interactions that influence process performance in an anaerobic membrane bioreactor [60].

\section{Membrane Fouling}

Membrane fouling continues to be a substantial challenge in advancing AnMBR technology considering membrane material costs and energy demands associated with fouling prevention [8]. As in most membrane filtration processes the flux declines during filtration. This is mainly caused by membrane fouling. Membrane fouling is significantly influenced by the hydrodynamic conditions, by membrane type and module configuration and by the presence of higher molecular weight compounds [61]. Experimental studies of AnMBR system revealed high COD removals; the viable suspended biomass was kept at a negligible level in the bioreactor. This is because the microbial cells move from the bioreactor to the membrane surface due to the high shear stress from the recycling pump. This shift from a suspended growth to an attached one gave rise to severe membrane fouling [14] [22]. System productivity could be reduced from membrane fouling, which cause frequent cleaning which might reduce the membrane lifespan and result in higher replacement costs, and increase the energy requirement for sludge recirculation or gas scouring [7]. The inorganic precipitation was observed, especially responsible for hardening the cake layer at the membrane surface where the strong binding and solidification led to pronounced external fouling. Based on a conceptual resistance-in-series model, the external fouling resistance gave a relatively large value of 30 times the internal fouling resistance [22].

\section{Membrane Fouling Control}

Optimization of operational condition is very important parameter for mem- 
brane fouling control. It was recommended that modification of sludge properties should be considered to obtain high fluxes in AnMBRs [62]. The external membrane configuration provides more direct hydrodynamic control of fouling, and offers the advantages of easier membrane replacement and high fluxes but at the expense of frequent cleaning and high energy consumption (of the order 10 $\mathrm{kWh} / \mathrm{m}^{3}$ product) [7] [63]. Figure 6 shows the summary of controlling parameters of Membrane fouling in an AnMBR.

It was found that poly-aluminum chloride as a flux enhancer and found that addition of $10 \mathrm{mg} / \mathrm{L}$ poly-aluminum chloride decreased fouling significantly in comparison to other tested adsorbents/coagulants including PAC, zeolite, and polyamide [7] [51].

\section{Comparison of AnMBRs with Other Treatment Technology}

AnMBRs have the ability to produce effluents similar in quality to those generated during aerobic treatment, while recovering energy and producing substantially less residuals [8]. AnMBRs are generally operated at higher biomass concentrations compared to aerobic MBRs, impacting rheology and thus, reactor hydraulics and pumping [32]. Conventionally configured rejection MBRs combine bio treatment with membrane separation by microfiltration (MF) or ultrafiltration (UF), with the membrane being placed either external to or inside the bioreactor. The membranes are usually of flat sheet (FS) or hollow fibre (HF) configuration if placed inside the bioreactor, or multi-tube (MT) if placed outside it [45]. In AnMBR also, Membrane separation with external and internal configuration is similar to that in MBR but membrane fouling is reported higher

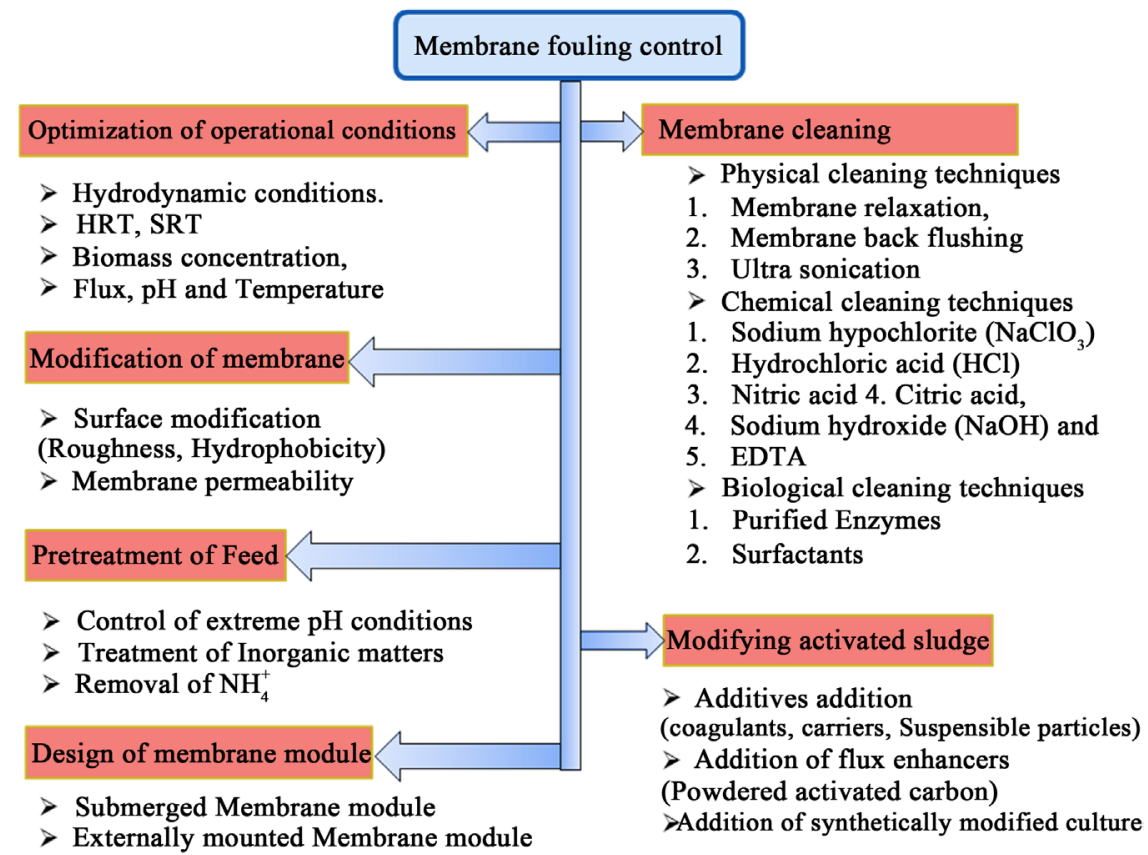

Figure 6. The Controlling parameters of Membrane fouling in an AnMBR. 
in AnMBR as compared to MBR [14]. Figure 7 shows the comparison of treatment processes of influent wastewater from primary treatment by (1) Activated sludge process, (2) Membrane bio reactor, and (3) Anaerobic Membrane bioreactor (AnMBR).

Table 2 indicates the comparison of two MBRs under aerobic and anaerobic condition. Interestingly the ammonia removal at elevated temperatures in aerobic MBR is higher due to stripping from the open reactor with high aeration rates. However, a similar type of ammonia removal processes were not displayed with AnMBR due to closed reactor conditions [6]. Because most AnMBR has used external cross-flow membranes, it is possible that, on average, AnMBRs have had a lower microbial activity compared to nonmembrane high-rate anaerobic systems [14].

\section{Summary of Review and Research Needs}

Operational costs related to energy requirements for gas/liquid recirculation for membrane fouling control and chemical costs required for membrane cleaning are still heavy burdens on the economic feasibility [32]. Due to low energy yields per gram of substrate, anaerobic bacteria grow very slowly and hence efficient reactor design needs to separate hydraulic retention time (HRT) from the solids retention time (SRT) [60]. Membrane fouling is a major constraint in advancing AnMBR technology.

Further research is needed to find suitable membrane material and membrane configuration for fouling control, determine the effects of additives on improvement of filterability and sludge deposition characteristics for AnMBRs [66]. However, a number of operational concerns exist, which need more detailed information for implementing full scale AnMBR for wastewater [8].

\section{Conclusion}

By anaerobic treatment, bioconversion of organic wastes to higher value

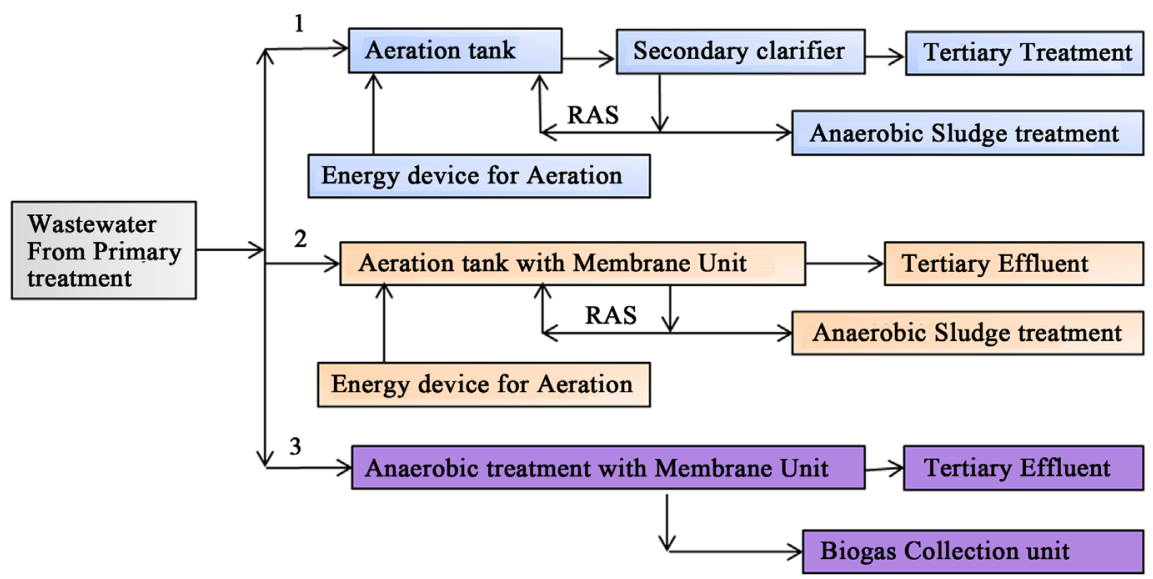

Figure 7. Comparison of treatment processes of influent wastewater from primary treatment, (1) Activated sludge process, (2) Membrane bio reactor, and (3) Anaerobic Membrane bioreactor (AnMBR). 
Table 2. Performances of aerobic MBR and AnMBR treating high-strength wastewater with similar properties [6].

\begin{tabular}{|c|c|c|c|c|}
\hline Parameter & \multicolumn{3}{|c|}{ Aerobic MBR [6] [64] } & AnMBR [6] [65] \\
\hline Wastewater & \multicolumn{4}{|c|}{ Molasses based synthetic wastewater } \\
\hline COD:N:P & \multicolumn{3}{|c|}{$100: 6.8: 1.3$} & $100: 5: 1$ \\
\hline HRT (h) & \multicolumn{3}{|c|}{8} & $32-48$ \\
\hline $\operatorname{OLR}\left(\mathrm{kg} \operatorname{COD} / \mathrm{m}^{3} \mathrm{~d}\right)$ & \multicolumn{3}{|c|}{25} & $8-12$ \\
\hline Feed COD (g/L) & \multicolumn{3}{|c|}{11} & $10-16$ \\
\hline Temperature $\left({ }^{\circ} \mathrm{C}\right)$ & 47 & & 60 & 55 \\
\hline COD removal \% & 83 & & 92 & 83 \\
\hline Nitrogen removal \% & 35 & & 39 & No major removal \\
\hline Ammonia removal \% & 59 & & 62 & No major removal \\
\hline Remarks & \multicolumn{3}{|c|}{$\begin{array}{l}\text { Ammonia stripping was reported as a major ammonia removal mechanism } \\
\text { at elevated temperatures with high rate aeration in an open reactor. }\end{array}$} & $\begin{array}{l}\text { Ammonia accumulation in } \\
\text { the closed anaerobic reactors }\end{array}$ \\
\hline
\end{tabular}

products and harmless substances has a significant role in environmental pollution control and improved resource utilization. Anaerobic Membrane bioreactors (AnMBRs) could be concluded as a promising technology for polluted wastewater treatment for energy recovery from generated organic waste and suspended solid free effluent because, by filtration through a membrane, the biomass has been separated from the treated water. After the discussion of many detailed features, applications and limitations from treatability and filterability point of view, it could be concluded that further research could make anaerobic membrane bioreactor, a possible best alternative technology for low cost treatment and operational feasibility.

\section{References}

[1] Xiao, X., Huang, Z., Ruan, W., Yan, L., Miao, H., Ren, H. and Zhao, M. (2015) Evaluation and Characterization during the Anaerobic Digestion of High-Strength Kitchen Waste Slurry via a Pilot-Scale Anaerobic Membrane Bioreactor. Bio Resource Technology, 193, 234-242. https://doi.org/10.1016/j.biortech.2015.06.065

[2] Khanal, S.K. (2008) Anaerobic Biotechnology for Bioenergy Production: Principles and Applications. John Willey \& Sons, Hoboken. https://doi.org/10.1002/9780813804545

[3] Umble, A. (2015) Anaerobic MBR: Challenges \& Opportunities, Hydrogen, Hydrocarbons, and Bioproduct Precursors from Wastewaters. National Renewable Energy Laboratory, Washington DC.

[4] Zayen, A., Mnif, S., Aloui, F., Fki, F., Loukil, S., Bouaziz, M. and Sayadi, S. (2010) Anaerobic Membrane Bioreactor for the Treatment of Leachates from Jebel Chakir Discharge in Tunisia. Journal of Hazardous Materials, 177, 918-923.

[5] Xia, T., Gao, X., Wang, C., Xu, X. and Zhu, L. (2016) An Enhanced Anaerobic Membrane Bioreactor Treating Bamboo Industry Wastewater by Bamboo Charcoal Addition: Performance and Microbial Community Analysis. Bio-Resource Technology, 220, 26-33. https://doi.org/10.1016/j.biortech.2016.08.057

[6] Visvanathan, C. and Abeynayaka, A. (2012) Developments and Future Potentials of 
Anaerobic Membrane Bioreactors (AnMBRs). Membrane Water Treatment, 3, 1-23. https://doi.org/10.12989/mwt.2012.3.1.001

[7] Lin, H., Peng, W., Zhang, M., Chen, J., Hong, H. and Zhang, Y. (2013) A Review on Anaerobic Membrane Bioreactors: Applications, Membrane Fouling and Future Perspectives. Desalination, 314, 169-188. https://doi.org/10.1016/j.desal.2013.01.019

[8] Smith, A.L., Stadler, L.B., Love, N.G., Skerlos, S.J. and Raskin, L. (2012) Perspectives on Anaerobic Membrane Bioreactor Treatment of Domestic Wastewater: A Critical Review. Bio Resource Technology, 122, 149-159. https://doi.org/10.1016/j.biortech.2012.04.055

[9] Rittmann, B.E. (1987) Aerobic Biological Treatment. Environmental Science and Technology, 21, 128-136.

[10] Visvanathan, C., Ben Aim, R. and Parameshwaran, K. (2000) Membrane Separation Bioreactors for Wastewater Treatment. Critical Review in Environmental Science and Technology, 30, 1-48.

[11] Smith, C.W., Di Gregorio, D. and Talcott, R.M. (1969) The Use of Ultrafiltration Membrane for Activated Sludge Separation. Proceedings of the 24th Annual Purdue Industrial Waste Conference, West Lafayette, 1300-1310.

[12] Fane, A.G., Fell, C.J.D. and Nor, M.T. (1978) Wastewater Treatment using a Combined Activated Sludge and Ultrafiltration System. Proceedings of Asian Pacific Confederation of Chemical Engineering, Jakarta, 21-23 November 1978, 117-129.

[13] Grethlein, H.E. (1978) Anaerobic Digestion and Membrane Separation of Domestic Wastewater. Water Pollution Control Federation, 50, 754-763.

[14] Liao, B.Q., Kraemer, J.T. and Bagley, D.M. (2006) Anaerobic Membrane Bioreactors: Applications and Research Directions. Critical Review in Environmental Science and Technology, 36, 489-530. https://doi.org/10.1080/10643380600678146

[15] Benefield, L.D. and Randall, C.W. (1980) Biological Process Design for Wastewater Treatment. Prentice-Hall, Englewood Cliffs.

[16] Li, A., Kothari, D. and Corrado, J.J. (1985) Application of Membrane Anaerobic Reactor System for the Treatment of Industrial Wastewaters. Proceedings of the 39 th Industrial Waste Conference, Ann Arbor, 627.

[17] Sutton, P.M., Li, R.R. and Korchin, S.R. (1983) Dorr-oliver's Fixed Film Suspended Growth Anaerobic Systems for Industrial Wastewater Treatment and Energy Recovery. Proceedings of the 37 th Industrial Waste Conference, Lafayette, 667.

[18] Strohwald, N.K.H. and Ross, W.R. (1992) Application of the Anaerobic Digestion Ultrafiltration Process to Brewery Effluent on a Laboratory Scale. Water Science Technology, 25, 95-105.

[19] Kang, I.-J., Yoon, S.-H. and Lee, C.-H. (2002) Comparison of the Filtration Characteristics of Organic and Inorganic Membranes in a Membrane-Coupled Anaerobic Bioreactor. Water Research, 36, 1803-1813.

[20] Sainbayar, A., Kim, J.S., Jung, W.J., Lee, Y.S. and Lee, C.-H. (2001) Application of Surface Modified Polypropylene Membranes to Anaerobic Membrane Bioreactor. Environmental Technology, 22, 1035-1042. https://doi.org/10.1080/09593332208618212

[21] Shimizu, Y., Rokudai, M., Tohya, S., Kayawake, E., Yazawa, T., Tanaka, H. and Eguchi, K. (1989) Filtration Characteristics of Charged Alumina Membranes for Methanogenic Waste. Chemical Engineering of Japan, 22, 635-641.

[22] Choo, K.H. and Lee, C.H. (1996) Membrane Fouling Mechanisms in the Membranecoupled Anaerobic Bioreactor. Water Research, 30, 1771-1780. 
https://doi.org/10.1016/0043-1354(96)00053-X

[23] Choo, K.H. and Lee, C.H. (1996) Effect of Anaerobic Digestion Broth Composition on Membrane Permeability. Water Science and Technology, 34, 173-179.

[24] Yanagi, C., Sato, M. and Takahara, Y. (1994) Treatment of Wheat Starch Waste Water by a Membrane Combined Two Phase Methane Fermentation System. Desalination, 98, 161-170.

[25] Yoon, S.H., Kang, I.J. and Lee, C.H. (1999) Fouling of Inorganic Membrane and Flux Enhancement in Membrane-Coupled Anaerobic Bioreactor. Separation Science and Technology, 34, 709-724.

[26] Kanai, M., Ferre, V., Wakahara, S., Yamamoto, T. and Moro, M. (2010) A Novel Combination of Methane Fermentation and MBR-Kubota Submerged Anaerobic Membrane Bioreactor Process. Desalination, 250, 964-967. https://doi.org/10.1016/j.desal.2009.09.082

[27] McMahon, J. (2010) Anaerobic Membrane Bioreactor System Treats High Strength Wastewater, 2010.

http://www.waterworld.com/index/display/articledisplay/364259/articles/membran es/volume2/issue-3/feature/anaerobic-membrane-bioreactorsystem-treats-high-stre ngth-wastewater.html

[28] Ho, J. and Sung, S. (2009) Anaerobic Membrane Bioreactor Treatment of Synthetic Municipal Wastewater at Ambient Temperature. Water Environment Research, 81, 922-928. https://doi.org/10.2175/106143009X407339

[29] Ho, J., Khanal, S.K. and Sung, S. (2007) Anaerobic Membrane Bioreactor for Treatment of Synthetic Municipal Wastewater at Ambient Temperature. Water Science Technology, 55, 79-86.

[30] Chang, S. (2014) Anaerobic Membrane Bioreactors (AnMBR) for Wastewater Treatment. Advances in Chemical Engineering and Science, 4, 56-61. https://doi.org/10.4236/aces.2014.41008

[31] Judd, S. (2008) The Status of Membrane Bioreactor Technology. Trends in Biotechnology, 26, 109-116.

[32] Ozgun, H., Dereli, R.K., Ersahin, M.E., Kinaci, C., Spanjers, H. and van Lier, J.B. (2013) A Review of Anaerobic Membrane Bioreactors for Municipal Wastewater Treatment: Integration Options, Limitations and Expectations. Separation and $\mathrm{Pu}$ rification Technology, 118, 89-104. https://doi.org/10.1016/j.seppur.2013.06.036

[33] Brian Shoener, D., Zhong, C., Anthony Greiner, D., Wendell Khunjar, O., Hong, P.-Y. and Jeremy Guest, S. (2016) Design of Anaerobic Membrane Bioreactors for the Valorization of Dilute Organic Carbon Waste Streams. Energy \& Environmental Science, 9, 1102-1112. https://doi.org/10.1039/C5EE03715H

[34] Martina, I., Pidoub, M., Soaresc, A., Juddc, S. and Jeffersonc, B. (2011) Review Article: Modeling the Energy Demands of Aerobic and Anaerobic Membrane Bioreactors for Wastewater Treatment. Environmental Technology, 32, 921-932.

[35] Dvorak, L., Gomez, M., Dolina, J. and Cernin, A. (2016) Anaerobic Membrane Bioreactors-A Mini Review with Emphasis on Industrial Wastewater Treatment: Applications, Limitations and Perspectives. Desalination and Water Treatment, 57, 19062-19076.

[36] Bornare, J.B., Raman, V.K., Sapkal, V.S., Sapkal, R.S., Minde, G. and Sapkal, P.V. (2014) An Overview of Membrane Bioreactors for Anaerobic Treatment of Wastewaters. International Journal of Industrial Research and Engineering, 1, 91-97.

[37] Martin-Garciaa, I., Monsalvo, V., Pidou, M., Le-Clech, P., Judd, S.J., McAdam, E.J. 
and Jefferson, B. (2011) Impact of Membrane Configuration on Fouling in Anaerobic Membrane Bioreactors. Journal of Membrane Science, 382, 41-49.

[38] Judd, S. and Judd, C. (2011) The MBR Book. 2nd Edition, Butterworth-Heinemann, Oxford.

[39] Kim, J., Kim, K., Ye, H., Lee, E., Shin, C., McCarty, P.L. and Bae, J. (2011) Anaerobic Fluidized Bed Membrane Bioreactor for Wastewater Treatment. Environmental Science and Technology, 45, 576-581.

[40] Sutton, P.M., Melcer, H., Schraa, O.J. and Tonga, A.P. (2010) Treating Municipal Wastewater with the Goal of Resource Recovery. Water Science and Technology, 63, 25-31. https://doi.org/10.2166/wst.2011.004

[41] Zhou, H., Li, H. and Wang, F. (2012) Anaerobic Digestion of Different Organic Wastes for Biogas Production and Its Operational Control Performed by the Modified ADM1. Environmental Science Health, Part A: Toxicl Hazard Substance Environmental Engineering, 47, 84-92.

[42] Skouteris, G., Hermosilla, D., López, P., Negro, C. and Blanco, Á. (2012) Anaerobic Membrane Bioreactors for Wastewater Treatment: A Review. Chemical Engineering Journal, 198-199, 138-148. https://doi.org/10.1016/j.cej.2012.05.070

[43] Van Zyl, P.J., Wentzel, M.C., Ekama, G.A. and Riedel, K.J. (2008) Design and Start-Up of a High Rate Anaerobic Membrane Bioreactor for the Treatment of a Low $\mathrm{pH}$, High Strength, Dissolved Organic Wastewater. Water Science Technology, 57, 291-295. https://doi.org/10.2166/wst.2008.083

[44] Jetten, M.S.M., van Niftrik, L., Strous, M., Kartal, B., Keltjens, J.T. and Op den Camp, H.J.M. (2009) Biochemistry and Molecular Biology of Anammox Bacteria. Critical Reviews in Biochemistry and Molecular Biology, 44, 65-84.

[45] Jeison, D., Plugge, C.M., Pereira, A. and van Lier, J.B. (2009) Effects of the Acidogenic Biomass on the Performance of an Anaerobic Membrane Bioreactor for Wastewater Treatment. Bioresource Technology, 100, 1951-1956.

[46] Belfort, G., Davis, R.H. and Zydney, A.L. (1994) The Behaviour of Suspensions and Macromolecular Solutions in Cross-Flow Microfiltration. Membrane Science, 96, 1-58. https://doi.org/10.1016/0376-7388(94)00119-7

[47] Lin, H., Chen, J., Wang, F., Ding, L. and Hong, H. (2011) Feasibility Evaluation of Submerged Anaerobic Membrane Bioreactor for Municipal Secondary Wastewater Treatment. Desalination, 280, 120-126. https://doi.org/10.1016/j.desal.2011.06.058

[48] Lin, H., Liao, B.-Q., Chen, J., Gao, W., Wang, L., Wang, F. and Lu, X. (2011) New Insights into Membrane Fouling in a Submerged Anaerobic Membrane Bioreactor Based on Characterization of Cake Sludge and Bulk Sludge. Bio resource Technology, 102, 2373-2379. https://doi.org/10.1016/j.biortech.2010.10.103

[49] Saddoud, A., Ellouze, M., Dhouib, A. and Sayadi, S. (2007) Anaerobic Membrane Bioreactor Treatment of Domestic Wastewater in Tunisia. Desalination, 207, 205-215. https://doi.org/10.1016/j.desal.2006.08.005

[50] Ho, J. and Sung, S. (2010) Methanogenic Activities in Anaerobic Membrane Bioreactors (AnMBR) Treating Synthetic Municipal Wastewater. Bio resource Technology, 101, 2191-2196.

[51] Wu, B., An, Y., Li, Y. and Wong, F.S. (2009) Effect of Adsorption/Coagulation on Membrane Fouling in Microfiltration Process Post-Treating Anaerobic Digestion Effluent. Desalination, 242, 183-192. https://doi.org/10.1016/j.desal.2008.04.005

[52] Gimenez, J.B., Robles, A., Carretero, L., Duran, F., Ruano, M.V., Gatti, M.N., Ribes, 
J., Ferrer, J. and Seco, A. (2011) Experimental Study of the Anaerobic Urban Wastewater Treatment in a Submerged Hollow-Fibre Membrane Bioreactor at Pilot Scale. Bioresource Technology, 102, 8799-8806.

[53] Dagnew, M., Parker, W., Seto, P., Waldner, K., Hong, Y., Bayly, R. and Cumin, J. (2011) Pilot Testing of an AnMBR for Municipal Wastewater Treatment. Water Environment Federation, 80, 4931-4941.

[54] Martinez-Sosa, D., Helmreich, B., Netter, T., Paris, S., Bischof, F. and Horn, H. (2011) Anaerobic Submerged Membrane Bioreactor (AnSMBR) for Municipal Wastewater Treatment under Mesophilic and Psychrophilic Temperature Conditions. Bioresource Technology, 102, 10377-10385.

[55] Le Clech, P., Jefferson, B., Chang, I.S. and Judd, S.J. (2003) Critical Flux Determination by the Flux-Step Method in a Submerged Membrane Bioreactor. Journal of Membrane Science, 227, 81-93.

[56] Speece, R.E. (1996) Anaerobic Biotechnology for Industrial Wastewater Treatments. Archae Press, Nashvillee.

[57] Lin, H.J., Xie, K., Mahendran, B., Bagley, D.M., Leung, K.T., Liss, S.N. and Liao, B.Q. (2010) Factors Affecting Sludge Cake Formation in a Submerged Anaerobic Membrane Bioreactor. Membrane Science, 361, 126-134. https://doi.org/10.1016/j.memsci.2010.05.062

[58] Brock, T.D. and Zehnder, A. (1978) Abstracts of the Annual Meeting of American Society of Microbiology. 78.

[59] Hansson, G. (1979) Effects of Carbon Dioxide and Methane on Methanogenesis. European Journal of Applied Microbiology and Biotechnology, 6, 351-359.

[60] Stuckey, D.C. (2012) Recent Developments in Anaerobic Membrane Reactors. Bioresource Technology, 122, 137-148. https://doi.org/10.1016/j.biortech.2012.05.138

[61] Melin, T., Jefferson, B., Bixio, D., Thoeye, C., De Wilde, W., De Koning, J., et al. (2006) Membrane Bioreactor Technology for Wastewater Treatment and Reuse. Desalination, 187, 271-282.

[62] Torres, A., Hemmelmann, A., Vergarai, C. and Jeison, D. (2011) Application of Two-Phase Slug-Flow Regime to Control Flux Reduction on Anaerobic Membrane Bioreactors (AnMBR). Separation and Purification Technology, 79, 20-25. https://doi.org/10.1016/j.seppur.2011.03.006

[63] Le-Clech, P., Chen, V. and Fane, T.A.G. (2006) Fouling in Membrane Bioreactors Used in Wastewater Treatment. Membrane Science, 284, 17-53. https://doi.org/10.1016/j.memsci.2006.08.019

[64] Abeynayaka, A. and Visvanathan, C. (2011) Performance Comparison of Mesophilic and Thermophilic Aerobicside-Stream Membrane Bioreactors Treating High Strength Wastewater. Bio resource Technology, 102, 5345-5352.

[65] Wijekoon, K.C., Visvanathan, C. and Abeynayaka, A. (2011) Effect of Organic Loading Rate on VFA Production, Organic Matter Removal and Microbial Activity of a Two-Stage Thermophilic Anaerobic Membrane Bioreactor. Bioresource Technology, 102, 5353-5360.

[66] Dereli, R.K., Ersahin, M.E., Ozgun, H., Ozturk, I., Jeison, D., van der Zee, F. and van Lier, J.B. (2012) Potentials of Anaerobic Membrane Bioreactors to Overcome Treatment Limitations Induced by Industrial Wastewaters. Bioresource Technology, 122, 160-170. https://doi.org/10.1016/j.biortech.2012.05.139 